SCHOLARS: Journal of Arts \& Humanities Print ISSN: 2773-7829; e-ISSN: 2773-7837

eJournal Site: www.cdetu.edu.np/ejournal/

- Peer-Reviewed, Open Access Journal

- Indexed in NepJOL; Star-Ranked in JPPS

Central Department of English

- Permanently Archived in Portico

Tribhuvan University

Kirtipur, Nepal

URL: www.cdetu.edu.np

Review Article

DOI: https://doi.org/10.3126/sjah.v4i1.43058

\title{
Anjum Hasan's The Cosmopolitans: A Critique of a Cosmopolitan Woman
}

\author{
Rama Islam, PhD \\ Department of English, Metropolitan University, Sylhet, Bangladesh \\ Corresponding Author: Rama Islam, Email: rislam@metrouni.edu.bd
}

\begin{abstract}
Anjum Hasan is a novelist, short story writer, poet and editor. Her third novel The Cosmopolitans (2015) deals with modern life of a cosmopolitan woman named Qayenaat who lives in a cosmopolitan city Bangalore. In cosmopolitanism, a person is free from the local or national bias and becomes a citizen on a global scale. This paper focuses on a sophisticated, fashionable, stylish and cultured woman who is a part of the cosmopolitan world. She is familiar with globalisation, Europeanisation and social process of transformation within the nation and beyond specific societies and cultures - the woman crosses the symbolic boundaries of national communities in India. The novel questions the place of art in modern life and portrays a lonely woman who is at odds with the world. As a cosmopolitan woman, she likes to work outside home and travels freely to different places. Concerned about commercialisation of art and culture and cosmopolitan citizens, she lives lonely in her father's house, and leads her life as a freelance editor and writer. Thus, the main objective of the study is to explore unconventionality and nomadic life of Qayenaat, who has failed as an artist in her life.
\end{abstract}

Keywords: Gender, cosmopolitan identity, culture, mobility, relationship

\section{Introduction}

The Cosmopolitans is an outstanding work by Anjum Hasan who was born in Shillong, India. The cosmopolitan refers to a citizen who is free from national boundaries and prejudices. It is considered a global citizen who minimizes the conflict between cultures and nations. The study concentrates on the life of a cosmopolitan woman named Qayenaat Gupta who lives in a cosmopolitan city Bangalore where people gather from different places of India as well as from all over the world. The word 'cosmopolitan' is related with the name as 'Qayenaat' means 'the cosmos' in Urdu language and it echoes the title of the novel, which is compound of 'cosmos' and 'polis'. A cosmopolitan feels comfortable to interact with the people of diverse cultures and considers the world to be home. Qayenaat, familiar with different countries, is associated with diversities and

Article History:

Submitted 14 November 2021

Revised 1 January 2022

Accepted 14 January 2022

Copyright Information:

Copyright 2022 (c) The Author(s). The publisher may reuse published articles with prior permission of the concerned author(s). The work is licensed under a Creative Commons Attibution 4.0 International License (CC BY 4.0).

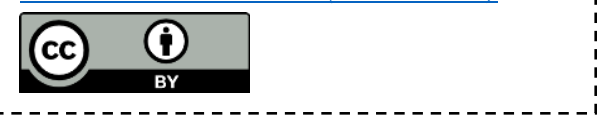

Volume 4, No. 1, February 2022 [pp. 87-98] 
carries a sense of borderlessness. She is an art lover whereas most of the people are professionals. She drops her surname and feels comfortable to define her identity with her name. Hasan, as a cosmopolitan authr, is compared with her protagonist Qayenaat who states, "Qayenaat, and I don't have a second name, just one name, Qayenaat, no caste, creed, religion, no nothing, just this" (188). As a citizen of a cosmopolitan society, Qayenaat does not feel the necessity of a name based on caste, religion, etc. She reflects on her cosmopolitan identity excluding her tie with any class, faith, religion, etc. Baban Reddy, a prominent artist, calls her as QT. She inwardly desires to be unique with her name to connect her identity from local to global.

Globalization is a central issue for the emergence of multiculturalism in the latter half of the twentieth and at the beginning of the twenty-first century. According to Mary Kaldor, cosmopolitanism is "a celebration of the diversity of global identities, acceptance and, indeed, enthusiasm for multiple overlapping identities and at the same time, a commitment to the equality of all human beings and to respect for human dignity" (92). The underlying concept of cosmopolitanism refers to interconnectivity, mobility and experiences that enable cross-cultural solidarity and a discrimination free world. Qayenaat is metaphorically well-off, because she can speak English, has freedom of movement, and can love and discard men. She interconnects with the unified city culture that coexists with traditional cultures, sub-cultures and super-cultures. She leaves her husband Sathi, but still she has a good friendship with him, which is not normal in the traditional Indian society. Multicultural world cultures and social practices change with the interaction and influence of different cultures. So, the cosmopolitan people are considered both the citizens of a single cultural community and the universal cultural community. Cosmopolitanism, a moral and socio-political philosophy, focuses on political institutions, moral norms, relationships, share markets and forms of cultural expressions.

\section{The Concept of Cosmopolitanism}

The cosmopolitan theory refers to the word 'cosmopolitan,' which is derived from the Greek 'Kosmopolites' that is formed from 'kosmos' meaning 'world or universe or cosmos' and 'polites' means 'citizen of a city or person of a city'. Cosmopolitanism, a fundamentally Western discourse, has got prominence in the $19^{\text {th }}$ century through the works of Karl Marx and Friedrich Engels. In The Communist Manifesto, they emphasize on "universal interdependence of nations" (Marx and Engels 14). Interconnection and interdependence of different nations in every direction are common in the contemporary cosmopolitan society and the cosmopolitan refers to the idea as 'citizen of the world'. The concept of cosmopolitanism has been coined by Cynic Diogenes of Sinope who asserts, "I am cosmopolitan!" (63). The concept of cosmopolitan discusses the concept that the global citizens who move with the idea of a shared morality, a shared economic relationship and a political structure that encircles different nations. Cosmopolitanism is a multidimensional concept, which originates from the Greek philosophical tradition of Stoicism and Kantian philosophy of the Enlightenment. In the Greek culture, a person is a citizen of a particular city. A cosmopolitan understands the implications of social, cultural and political transformations. Vertovec and Cohen have given some ideas on cosmopolitanism. Martha Nassbaum, the most fervent supporter of cosmopolitan society, explains cosmopolitanism as the ability to "recognise humanity wherever it occurs, and give its fundamental ingredients, reason and moral capacity, our first allegiance and respect" (7). In a cosmopolitan culture, the people from different countries and diverse cultures make relationships with their mutual respect. Home and the world intermix and the private 
becomes public and public becomes a part of each other in a cosmopolitan society. Cosmopolitanism is related to some universal concepts like freedom of speech and human rights.

The cosmopolitan cities have diverse cultures and strong unifying city cultures that join people of many cultural identities who speak in different languages. Diversity, civility, sophistication, economy, quality of life, creativity and tourism are the features of cosmopolitanism. Cosmopolitan identity is related to globalization. According to Zygmunt Bauman, "Globalization divides as much as it unites; it divides as it unites the causes of division being identical with those which promote the uniformity of the globe" (2). Globalization unites and divides the people and it makes a connection and uniformity between the local and the global. Bauman emphasises cosmopolitanism in the domain of the mobile. Mobility is the realistic option in a world of permanent change. There are three major tenets of cosmopolitanism: individualism, universalism and generality. The individual is the ultimate unit of concern and analysis; every person, irrespective of class, gender, race and religion, is universal and is equally worthy of respect and recognition by others. The whole humanity is generalized and is entitled to fair and impartial treatment. Mobility is more visible in the case of humans, but Hasan shows the mobility of a woman, Qayenaat, who is extremely individualistic and chooses an exceptional life without obligations and expectations for the material gain. Hasan also shows that the cosmopolitan women fight against the traditional concepts as Qayenaat is against the arranged marriage and the oppressive husband.

Cosmopolitanism is connected with the universalism of modern Western thought; but the sentiments of cosmopolitanism are not restricted to the Western world. Qayenaat's cosmopolitan attitudes and cosmopolitan lifestyle form a different type of identity, which is against the idea of belonging to a particular culture. A specific culture is not an essential aspect for the formation of one's cosmopolitan identity. A cosmopolitan has absolute freedom to accept a wider range of culture or reject the noncultural expressions. Qayenaat likes to appreciate multiplicity and diversity of things, which emphasise the elements of becoming, change and novelty. In an article titled "The cosmopolitan imagination: critical cosmopolitanism and social theory" Gerard Delanty writes, “. . . culture as an on-going process of construction as opposed to being embodied in a particular way of life. This perspective reinforces the notion of cosmopolitanism as a mode of cultural framing which is not reducible to rights or particular identities, but concerns cultural models by which the social world is constituted" (30-31).

There is a common concept that cosmopolitanism represents the elitist culture, which is against the culture of the mass. In the modern world, the ideas and sentiments of cosmopolitanism spread in the lower stratum of society. There are two different types of cosmopolitanism: "high" and "low". So, culture in cosmopolitanism is an ongoing process of construction. Delanty rightly states, "Cosmopolitanism thus reflected the revolt of the individual against the social world, for to be a 'citizen of the world' was to reject the immediately given and closed world of particularistic attachments. Not surprisingly it became associated with the revolt of the elites against the low culture of the masses" (26). Since all cultures have to deal with the other, a cosmopolitan has to struggle to form a global identity, rejecting his/her attachment on a particular culture. There is a cultural openness in cosmopolitanism and the culture is completely part of the economic base. As a transdisciplinary idea, cosmopolitanism is one of the major fields in philosophy, sociology, social theory and cultural studies.

Hasan's The Cosmopolitans is a cosmopolitan novel, which thematically engages with different cosmopolitan aspects like economy, mobility, politics of identity and belonging. The notions of identity, movement, belonging and oneness in a world 
happened for globalization and transnationalism. In Secularism in the Postcolonial Indian Novel: National and Cosmopolitan Narratives in English, Neelam Srivastava shows that cosmopolitanism is "an intellectual reaction a response to excessively restrictive notions of identities and identitarian politics" (157). Identity shifts and hybridized identity is created, which challenges the traditional notions of belonging and identity. A cosmopolitan becomes rootless and in "Minority Cultures and the Cosmopolitan Alternative," Jeremy Waldron shows a self who refuses "to think of himself as defined by his location or his ancestry or his citizenship or his language" (754). A cosmopolitan is defined as a migrant by Salman Rushdie and a perpetual refugee by Jean-Jaques Rousseau. Cosmopolitan identity creates a relation between a self and the world because the world economy is so much interdependent due to globalization.

The interrelation of different countries and cultures blurs the boundaries of different nations. In The Gutenberg Galaxy: The Making of Typographic Man, Marshall McLuhan writes:

... We can now live, not just amphibiously in divided and distinguished worlds, but pluralistically in many worlds and cultures simultaneously. We are no more committed to one culture - to a single ratio among the human senses - any more than to one book or to one language or to one technology ... the human family now exists under conditions of a "global village." (31)

Cosmopolitanism is not only relevant globally, but also it is relevant locally. There are some cosmopolitan cities in India like New Delhi, Chennai, Mumbai, Bangalore, etc. where people like diversity, follow modern style and arrange art festivals.

\section{Qayenaat as a Cosmopolitan Citizen}

A cosmopolitan citizen feels himself advanced for his or her interaction with the people from different backgrounds. Qayenaat is an art teacher at a local school and later writes art reviews for whoever would take them and finds a job as an assistant in an Altamount Road art gallery. She lives at M.G. Road situated in the modern centre of the city, a centre of world culture, trade, tourism and migration and where the people and their customs and cultures mingle and interact. The lifestyle is very expensive and Hasan portrays the city as ". . . in Indira Nagar and Koramangala, Whitefield and Yeshwantpur - the 'lifestyle enslaves', the mammoth malls, the high streets of international fashion and global entertainment, the bars, bistros and boulangeries" (81). There are some places in Bangalore where international standard and fashionable malls, bars, bistros and boulangeries are available. These places are commercial, sophisticated, fashionable, expensive and international standard. They are representing the postmodern consumer culture where opportunities are endless and everything is commodified. Hasan shows that the city turns into a centre of consumption with shopping malls and museums. But it also becomes chaotic, streets are narrow and haphazard, and the people are always busy.

In consumer capitalism, lifestyle and taste change and society transforms. The reality of the citizens of Bengalore is that the people observe from their beautiful apartment a polluted lake and hectic slum, which are very common pictures of a cosmopolitan city. The city is filled out in every direction and the municipal office takes care of the garbage of the city. Still there are some problems in M. V. Nagar, especially they don't get water from the river Kaveri. There are many damaged water pipes in the city and thirty percent of water goes waste. The citizens do not care for problems; rather they become habituated with the problems. Qayenaat observes all these crises and becomes used to with pollution and mismanagement of the cosmopolitan city. Administration does not have any special plan to spend some money for repairing and 
changing. Despite all obstacles and problems, the cosmopolitan citizens appreciate a materialistic life and the real art has no meaning in their lives.

Cosmopolitanism maintains that identities are fluid and not geographically or culturally bounded. Qayenaat talks on different contemporary issues with her known people, but she is a silent, floating, solitary and sensitive woman at the edge of Bangalore's art scene. She does not bother any traditional social bond and social stigma in her free life. Her father is a civil engineer who is more an engineer than a father and is always incomprehensible to her. She gets an opportunity to move to many cities like Calcutta, Mysore, Guwahati, Patna, Indore, Delhi and Bhubaneswar due to her father's job. Her nomadic movement from one place to another around the country makes her different psychologically from other Indian women. She has come into contact with different weather and multi-cultured people. She learns to inhale the acrid smoke of a beedi 'cigarette' from a cook's daughter in Patna. She is unlike Sara and Sathi and is permanently unsettled and floating. Normally, most of the Indian women of her age have family and they remain busy with domestic work or women who work outside also remain busy with homely and official works. Both housewives and professionals of India are domesticated and silently work at home and outside. Qayenaat lives far away from family and conventions and prefers leading her life in her own way. She expresses, "I'm living my own life now, remember? .. I want you to leave me alone" (126). Qayenaat prefers leading the life in her own way and she enjoys loneliness and feels happy without company. She does not care and lament for the fragmentation in relationships. In Literary theories and Criticism Beyond Modernism, Avik Gangopadhyay claims, “. . . postmodernist politics offers a way to theorize local situations as fluid and unpredictable, though influenced by global trends" (59). By the influence of globalism, the local identity transforms and continuously changes. The identity is fluid and changeable. Qayenaat rejects stable identity and accepts fragmented, global and floating identity.

Cosmopolitans are polite and courteous in behavior and speech. The positive implication of a cosmopolitan city is that there is a significant degree of social harmony shared with different cultural elements as languages, norms and a sense of community. Qayenaat's global identity contradicts with the local identity as she has friends from different cultural backgrounds because they speak in different languages. They pass time with the modes of recreation and enjoyment. A cosmopolitan is very conscious about the latest fashion, designing, cosmetics, make-up and perfume. Quyenaat likes the Western dresses as pants, batik scarves and men's shirts. She occasionally wears Indian sari and bangles. She not only changes herself psychologically, but also she wears men's dresses, which can identify herself as a cosmopolitan woman. She gathers a vast knowledge of the world through reading lots of books as she perceives, "Perhaps that's why. I have this problem of seeing the world, the entire complicated mass, all at once, so I can never achieve the simplicity that is needed to concentrate on the genuinely good bits" (76). She knows more and discerns the world very problematic. She explores that she will never achieve simplicity because the people of the world are complicated. Her observations of the contemporary world make gloomy and pessimistic.

\section{Gender and Cosmopolitanism}

Gender identity is a big issue in the patriarchal society. Qayenaat is not genderbiased and she mixes with both males and females who are from different countries. Moreover, she does not feel that her female identity is a barrier for mixing with all categories of people. She raises herself above the sense of gender distinction and discrimination between man and woman. The concept of gender has become a common idea during the early 1970s. The idea analyses a binary division between the biological 
sex differences as 'masculine' or 'feminine'. The term is a cultural or social construction of sex that is stated in Contemporary Literary and Cultural Theory: From Structuralism to Ecocriticism in this way: “. . . gender is a social construction” (Nayar 90). Gender is an issue where a society defines the identity of women who most of the time are discriminated by the society. The notion 'gender' helps to create consciousness among women that they are naturally better suited in the 'domestic' roles. In the contemporary cosmopolitan society, women are not subordinated and discriminated by patriarchy what the traditional women face. Women are equally participating in all places as Hasan portrays a fifty-three year Qayenaat who ". . . felt strangely tranquil. Perhaps men and women fought bitter wars only because they longed to be consumed by each other, whereas what really worked was a sense of fellowship" (33). She feels that both men and women fight to dominate each other, but she feels relaxing in the domestic sphere as she sees a bitter conflict between Sathi and her because they want to overcome each other. In her free life, she even does not show any attachment for family and any connection with the society and traditional norms. She is hardly tormented by marriage though she has left her ex-husband, Deepak. She does not face the dominion and power of men over her personal life. As a global citizen, she denies the traditional social position where women are treated as "emotional (irrational), weak, nurturing, and submissive" (Tyson 85).

Weakness, emotion and submissiveness are common in the traditional women, which are absent in the cosmopolitan citizen. Qayenaat's cosmopolitan sense enables to cross limits from the space of otherness. The global consciousness helps her to contest against the patriarchal, capitalist and racist power domains.

The common concept of people is that home is the best place for women because they should not have individual choice. Gender defines women's identity as in Sex, Gender and Society, Ann Oakley writes, "To be a man or a woman, a boy or a girl, is as much as a function of dress, gesture, occupation, social network and personality" (158). Different cultures define the gender position differently and dress, gesture, occupation, social network and personality are important elements to identify masculinity and femininity. Qayenaat possesses a sense of human being as she prefers to stay outside the home. She likes to pass time with Sara; she feels comfortable to share everything with her; and she can't think her life without the inspiration of Sara. She also has friendly relations with her former husband, Sathi, as she mentions to Baban, "Oh no, no, no. We were together once. No, not any more. Live in Delhi. Just visiting" (119). She freely expresses that though she is separated from Sathi, he sometimes visits Bengalore. There is nothing common between her and Sathi, but she keeps her relationship with him. In a cosmopolitan society, there are some men who support women in standing up against the pressures of men and society.

Qayenaat does not prefer to confine herself in the domain of masculinity. She is like Sophie, a young woman in Bangalore, of Hasan's second novel Neti, Neti. Sophie is neither happy in the hometown she has left behind, nor the big city where she finds herself rootless. Avoiding all kinds of subjections and obstacles, Qayenaat adjusts herself with the real situation. Hasan, in The Cosmopolitans, writes, ". . . we are victims of today, hostage to tomorrow, and nostalgic for yesterday" (4). People suffer in city; they are the prisoners of tomorrow and become nostalgic for past memories. The concepts of present, future and past haunt Qayenaat. She is surrounded with the people who ignore artwork, pass time with watching TV, drink wine and most of them are busy to attain celebrity. She does not have any prejudices to pass time with her friend, ex-husband and others who are from different cultures, religions, etc.

Gender and cosmopolitanism are very contemporary and prominent approaches. People pursue specific careers and lifestyles and emphasis on how to make women thin, 
beautiful and desirable to men. Women's roles in the cosmopolitan society are very challenging and they feel themselves connected with the world. Qayenaat thinks that she's a global citizen and does not want to be recognized like other women. She even recognizes none as she has stopped recognizing children. According to the author, "Qayenaat was permanently unsettled because of her memories were tied to ghostly places; it was impossible to go back to them" (88). Qayenaat does not have permanent home; her past memories are tied to ghostly places; and she can't go back. She searches for identity and root. The cosmopolitan feminine identity refers to a sense of global women's right and free from the patriarchal oppression. The global feminist consciousness is taken from Chandra Mohanty.

Women cross boundaries as in her late thirties she realizes that the most miraculous thing of human life is that the people are doing the same works, eating the same kinds of food and having the same kind of pointless conversations with their husbands or wives. Nothing is exceptional in the life of common people. Christopher Butler writes, "The postmodernist self, then, is very differently conceived from the self at the centre of liberal humanist thought, which is supposed to be capable of being autonomous, rational, and centred, and somehow free of any particular cultural, ethnic, or gendered characteristics" (59). Self-identity in a postmodern society is nourished by liberal humanism and with the thinking of biased-less regarding culture, ethnicity and gender. Qayenaat wants to change her life doing extraordinary works. She has a different outlook and has no connection with the local world of her father's birthplace. She has an attachment for the cosmopolitan society and sometimes feels attracted to her exboyfriend Sathi who belongs to a higher and ephemeral culture. Hasan writes about “... their break-up had been partly this too. She stopped finding his rustic accent quaint; she grew tired of his mockery of the cosmopolitans. She decided one day that they had nothing in common, but it had taken a long time to convince Sathi" (39). Sathi's cosmopolitan approaches make her tired as mockery is common in the cosmopolitan citizens.

\section{Consumerism and Cosmopolitanism}

In India, thousands of people are moving to city to attain a cosmopolitan life. All want to be the global citizens and become ambitious for economic growth. These new combined people play an important role for economic growth and social change in the cosmopolitan cities. They feel uncomfortable in their ways of life and suffer from nostalgia and identity crisis. Qayenaat experiences the positive and negative images of Bangalore and lives here for her love for art. She dislikes the insurance companies who exist to make money from human insecurity. The cosmopolitan life gives her Eurocentric concept of liberal outlook, which makes her easy to adjust with everyone. She is necessarily conscious to embrace a cosmopolitan culture.

Culture is important to change the identity of a human being. The cosmopolitan citizens follow high culture, and fine arts and opera are highly accepted for them. In the cosmopolitan society, the people always reevaluate and transform cultures and form a new culture. The highest form of cultures of opera, pop culture of theatre, subcultures of neighbourhood and traditional cultures of ethnic neighbourhood bring change in a cosmopolitan life. In A New Cosmopolitanism: Toward a Dialogue of Asian Civilizations Ashis Nandy writes, "Cultures do not usually learn from each other directly; they own up to new insights as only a reprioritization of their own selves, reevaluation of some cultural elements and devaluation of others" (131-132). Culture is not a subject to learn directly; rather it is achieved through interaction. New identity can be formed through reprioritization and reevaluation of cultures. Qayenaat carries a new culture, which is 
acquired by interaction with others. When Sathi and Qayenaat were the couple, she comes to know the tastes of different kinds of foods, which is dissatisfied that how much she loves others she does not get back equally. She is a person of modernity, conscious and proud living in a mixed-up society and having a mixed-up self. Staying in the city, she interacts with diverse cultures. In "What is Cosmopolitan?" Jeremy Waldron remarks, ". . cosmopolitan attitudes and cosmopolitan lifestyles, where the adjective is supposed to indicate a way of being in the world, a way of constructing an identity for oneself that is different from, and arguably opposed to, the idea of belonging to or devotion to or immersion in a particular culture" (227). Every culture is distinct and the cosmopolitan refers to the way of existing in the world and makes a different kind of identity. As culture is a matter of valuing diversity and celebrating difference, cosmopolitanism highlights on those aspects that clearly distinguish it from one's own. Diversity and difference of cultures change one's personality in a cosmopolitan city. The multicultural society constitutes with a lots of differences in costumes, language and ritual. Qayenaat's Indian woman's identity changes and transforms into a different personality. There is a combination of cosmopolitanism and localism in her.

The economic growth of the cosmopolitan city leads to a global competition. A large number of businesses and individuals get an entrepreneurial spirit. Qayenaat observes that the people are "ruthless capitalists" (Hasan 6). The cosmopolitans are bogus and measure art from the capitalistic perception. Art is a matter of heart and material gain is just the opposite of art. The capitalistic thinking of the cosmopolitan society hurts Qayenaat and Sara. In their conversation, Sara remarks, "That is not art. I don't know what that is, but it's not art. Anyone who pretends otherwise is a snob. We are not art-viewing machines; we are human beings" (13). Sara expresses that art is not really appreciated properly by cosmopolitans who are snobbish and just like art-viewing machines. Qayenaat searches a meaning in life and expects a meaningful art in city.

The novel questions the place of art in a modern life. Qayenaat is a lover of art as she states, "I am actually just an appreciator of art" (129) and she observes, “. . . people ignored the artwork and drank wine, their conversation muffled by the creamy canapes they were stuffing their mouths with, their sidestepping movements signaling high excitement" (4). Qayenaat thinks that art is modern and is known, small, collegial and informal with art. She perceives that the people have no interest on art in the contemporary time because they are materialistic. Gyan Pai writes, "This is Qayenaat. One of the few art lovers left standing. The rest of us are just professionals" (158). Qayenaat loves art, reads books, looks at paintings and enjoys dance though it does not bring money. Capitalism leads them to involve with drinking, conversation, eating and showing artificial excitement for art. At the centre, she discerns a competition between TV and art as many people like to watch TV than go to galleries to enjoy artworks. Sathi expresses, "They'll give you money. The painting is five times more valuable today, so that's a factor in your favour. And it's being stolen is nothing out of the ordinary, the artist's name is on everyone's lips. It's very simple" (73). All welcomes money and Hasan shows how art turns to mechanization and commercialization where people measure everything and all qualities with money. Jyoti states, "The market. The market must rule! The more productivity, the more money. The more money, the quicker it will tackle down to those who don't currently have it and the happier everyone will be. It's quite simple" (147-148). Business, market and money are very important in the capitalistic society and money of the capitalistic society cannot make everybody happy. Jyoti truly identifies that the cosmopolitans are ruled by money.

Cosmopolitanism represents the world as a marketplace and is constantly competing with the ideas and values of others for power. Money plays a significant role 
in the citizens of Bangalore. It can make multiple identities within a man. The people who have money can do anything and feel that the world is in their hands. Even girlfriends leave their lovers if their boyfriends not have not money. The people are so much materialistic that they are not interested to communicate with others. Manohar says, "But now it is all about money. All ab-out money. Money's gone up, humanity's gone down" (112). Money is closely related with the human relation in a cosmopolitan city. There is no money, there is no humanity. The people have everything, but they are not happy. The cosmopolitan woman discourse featured in the marketplace that may act as an emancipating force for women who originated in a patriarchal society. Qayenaat gets strength to fight against the patriarchy due to the senses of individualism and economic power.

Though Qayenaat lives in the modern centre of the city and sometimes walks on the streets of Sir M.V. Nagar where the people from different places come, settle, coexist and adjust every day. She feels this place as marvelous as the inhabitants are from the middle class, hard-working, modest with strict morality and progressive. Hasan says, "Nonetheless, she - admirer of her neighbourhood's unremarkable cosmopolitanism was herself an oddity here" (108). She is single and admires the cosmopolitan life. She goes to the yoga school and clearly reads the questions and complaints of her neighbours. She comes into contact with various food habits, religions and languages in M.V. Nagar.

The creative people feel attracted to the cosmopolitan city for a significant output of their artistic work. They expose their diverse experiences in the motivating setting. Baban Reddy, a world famous artist, returns from America to Bangalore to show his latest artwork, Nostalgia, a new creative artwork. He is the main attention to many admirers as Sara says, "He's too big for Bangalore" (11). The presence of IndianAmerican Reddy sets Qayenaat to the past, the most unexpected journey of her life. She is uttered QT by Reddy who crushes Qayenaat in a hug. She herself sets fire to Nostalgia and the bystander suffocates to death in the ensuing smoke. She travels from the city to the village, and discusses about art and culture. She thinks herself as an ideal citizen of the city. His presence rekindles their long ago sparks of love; but the time changes the relationship. Hasan writes, "Qayenaat considered calling Baban, asking if he could pick her up, but it felt daunting to explain where she lived, get him to travel the physical and mental distance between posh, moneyed, famous, vast Whitefield and once-significant but now unknown, anonymous, suburban, shabby, small Sir M. V. Nagar" (110).

Qayenaat's old longings rise, but both are the in-between gorgeous artificial world and the poor world. She goes to the bar with Baban and takes wine. Wine does not help to stop anxiety as she expects something more forceful. The cosmopolitans do not behave correctly in the relationships and men are perceived as incapable of understanding the women's needs and wants. Raddy's returning to Bangalore makes Qayenaat nostalgic and she is repressed by her memories and experiences. She realizes and tells Reddy, "You were never crazy about me. You like to hang out with me and pass the time, that's all" (122). The cosmopolitan citizens are not serious about the love relationship. Once they were friends and Bangalore was innocent of pelf at that time. Qayenaat never finds seriousness in Reddy about their relationship. The craziness what she wants from him, she does not find that. Love is commercialized and it is not a matter of commitment to the cosmopolitans.

After Baban's leaving, Qayenaat sees this material world growing louder around her. Pramod K. Nayar observes, “... cosmopolitanism can be built on a common ethics of recognition; where we acknowledge the suffering of the Other and work to fight the institutional forms of suffering everywhere" (181). Cosmopolitanism reflects that the people of Third World countries find themselves as Other and fight against the 
dominating institutions. Qayenaat feels herself inferior in front of Reddy. She cannot tolerate Reddy's relationships with Tanya who wants to live in New York and Sara. She suffers for her past memories, but Baban only misses his past relationship with Qayenaat. Their relationship could not materialize due to the differences of their ages. Baban says to Qayenaat, "After all that time when you knew I was crazy about you and you were too proud to do anything about it. It was all yours, QT" (Hasan 121). Qayenaat never gets Baban's close attachment for her. She likes to escape from young man's affections and has deliberately driven him from the city to make his life anew in a foreign country. In the present moment, Baban feels her as a "proud woman, proud woman, proud woman, proud woman" (122) of the city. Reddy's artwork, Nostalgia tortures her. Committing an unforgivable crime, she flees to a rural part of India to avoid the repercussions of her crime. She confesses, "Yes, I ran away in misplaced fury and destroyed an artwork and killed a man for nothing but my despicable vanity" (164). She destroys the artwork due to her ego. She feels guilty for the killing Gyan Pai and destroying the artwork Nostalgia.

Qayenaat realises that she is not only responsible for the death of Pai, but also for the death of her mother. During her childhood, she had a wonderful friendship with Kamna who had brought a great change in her life. Qayenaat was very reserved and serious before twelve. Kamna's company had broken the shell of stoicism of her. Both used to smoke 'beedis' (166) and discuss how men oppressed women at home physically and psychologically. Kamna's disappearance broke her heart, so she wanted her mother to do something to bring Kamna back. Seeing Qayenaat adamant and inconsolable, her mother died of heart attack. The past memories torture her. Hasan says, ". . . every time Qayenaat tried to close off the past and bring her mind back to the present, it slipped from her grasp and returned to a contemplation of those old, unhappy, far-off things, and battles long ago" (173). The past memories haunt her though she wants to forget. She contemplates on the old, unhappy past memories.

After the tragic event in her life, Qayenaat contacts an aficionado of dance named Pathak and goes to a town Simhal, the place is known for Natyashastra, a dance of ten years old. She visits the Modern Nritya Academy, a modern place both in name and appearance. She explores an extraordinary entity of Indian culture. Her relation with the king leads to frustration. She thinks it is absurd that the king talks with the poor and primitive people politely. But the king says, "Primitive? What is your heritage Mandakini? Don't you belong to this nation of the snake worshippers and idolaters? Don't you know that we undertake to marry frogs and donkeys when the rain fail? Our rivers are holy and our trees are sacred. .." (337-338). As a cosmopolitan woman, Qayenaat forgets that she is an Indian and scolds the king for his friendly mixing with everyone. She has come to Simhal to forget her commercial life. She forgets that the less she differs from other people, the more she falls in line. She is disconnected from her roots and culture. She thinks that "she was the first cosmopolitan to sleep on that aged mattress, to sit on the stone by the river, to share the meat of a freshly slaughtered goat with the king" (278-279). The situation changes her and she tries to adjust. The king states, "Culture becomes mannered, baroque. Characters in plays and novels were supposed to cultivate social graces, not bare their souls or, for that matter, their bodies" (290). It denotes the attachment on the European architecture, music and art. Artificiality and ornamentation get more privileges in a culture as the classical dancers express their complex emotions.

Qayenaat is greatly attached and influenced by the modern civilization, Westernization and city life, which lead her to meaninglessness. Hasan writes, "Her brave secular outlook - the belief that she was herself and not the function of her antecedents - sagged a bit when presented to her fellow men" (190). She is materialistic 
and egoist. Once the king stated, "You're not bored of my world. I worry every day that you will leave, go back to the air-conditioned comfort of Bangalore. That I must some day. I have my own old things to look after" (297). This indicates that Qayenaat is made of a cosmopolitan culture and it is natural that she will not stay in the village forever. She feels nothing in herself and returns to the city with Malti's son Chota though she is so much the wrong candidate for motherhood. She feels the necessity of an honest job to survive and to take care of Chota. As an art lover in her critical moments again and again, she takes shelter in art what brings her back to life in a small way.

\section{Conclusion}

In sum, the cosmopolitan identity is formed through shared norms, values, behaviours, institutions and rituals. In The Cosmopolitans, Qayenaat was born in a traditional society, but she seeks broad cultural experience and transforms herself into a cosmopolitan with time. She knows English; she has freedom of movement; she loves men and sometimes discards them; and in her lonely life, she searches for her identity. No authoritarian forces like society, morality, religion can change her; she changes herself in association with the culture of an international city. In the novel, Hasan deals with multiple identities, which are non-static and not exclusive to the national borders. The cosmopolitans are uncomfortable in the swim of the big city and are often between nostalgia and self-discovery. Qayenaat is frustrated seeing commercialization in art as David Lyn in Postmodernity states, "The sense of fragmentation and uncertainty seen in today's art and architecture, movies and music, creates a new cultural collage, a mélange of styles and products that collapse into each other in kaleidoscopic confusion" (90). There is an uncertainty in the postmodern art-forms, which are fragmented. The cosmopolitan transformation focuses on translations and transformation of modernity. Qayenaat's life has been a series of questions and musing on art, its many meanings, on different loves, on people, their fates, on bodies and how they decide one's destiny and her place in it all. She is a wandering, rootless and decidedly unsettled woman as her personality improves through the intercultural and interpersonal relations. Hasan portrays the life of a cosmopolitan woman who prefers change and mobility.

\section{Works Cited}

Bauman, Zygmunt. Globalization: The Human Consequences. Polity Press, 2005.

Butler, Christopher. Postmodernism: A Very Short Introduction. OUP, 2002.

Delanty, Gerard. "The Cosmopolitan Imagination: Critical Cosmopolitanism and Social Theory." The British Journal of Sociology, vol. 57, no. 1, 2006, pp. 25-47.

Gangopadhyay, Avik. Literary Theories and Criticism beyond Modernism. Books Way, 2015.

Hasan, Anzum. The Cosmopolitans. Penguin Books, 2015.

Kaldor, Mary. New and Old Wars: Organized Violence in the Global Era. $2^{\text {nd }}$ ed., Polity Press, 2006.

Laertius, Diogenus. Lives of Eminent Philosophers. MA, 1925.

Lyon, David. Postmodernity. Viva Books Private Limited, 2002.

Marx, Karl and Frederick Engels. The Communist Manifesto. Elec Book, 1998.

McLuhan, Marshall. The Gutenberg Galaxy: The Making of Typographic Man. U of Toronto P, 1962.

Nandy, Ashis. "A New Cosmopolitanism: Toward a Dialogue of Asian Civilizations." The Inter-Asia Cultural Studies. Edited by Kuan-Hsing Chen and Chua Beng Huat. Routledge, 1998. 
Nayar, Pramod K. Contemporary Literary and Cultural Theory: From Structuralism to Ecocriticism. Dorling Kindersley Pvt. Ltd, 2010.

Nussbaum, Martha. "Partriotism and Cosmopolitanism." For Love of Country: The New Democracy Forum on the Limits of Patriotism. Edited by J. Cohen. Beacon Press, 2002, pp. 3-17.

Oakley, Ann. Sex, Gender and Society. Gower Publishing Company Limited, 1985.

Srivastava, Neelam. Secularism in the Postcolonial Indian Novel: National and Cosmopolitan Narratives in English. Routledge, 2008.

Tyson, Lois. Critical Theory Today. Routledge, 2006.

Waldron, Jeremy. "Minority Cultures and Cosmopolitan Alternative." University of Michigan Journal of Law Reform, vol. 25, no. 3 \& 4, 1992, pp. 751-793.

---. "What is Cosmopolitan?" The Journal of Political Philosophy, vol. 8, no. 2, 2000, pp. 227-243.

\section{To cite this article [MLA style]:}

Islam, Rama. "Anjum Hasan's The Cosmopolitans: A Critique of a Cosmopolitan Woman." SCHOLARS: Journal of Arts \& Humanities, vol. 4, no. 1, February 2022, pp. 87-98. NepJOL, doi:10.3126/sjah.v4i1.43058. 